\title{
Macrogeographic and micrographic comparative study of risk factors for gastric cancer in Japan, China and South America
}

\author{
Toshiro TAKezaki $^{1}$, Toshinobu Fujiyoshi ${ }^{2}$ And Kazuo TaJima ${ }^{1}$
}

\section{RESUMEN}

El nordeste de Asia (Japón, Corea, China) es una de las áreas que tiene el mayor riesgo en el mundo para sufrir cáncer gástrico (CG). Sin embargo, el CG es también común en Centro y Sud América en países como Costa Rica, Colombia y Chile, además de países latinos de Europa como Italia y Portugal.

Un Aumento del riesgo para el CG ha sido reportado en fumadores, bebedores de alcohol, o personas con el hábito de consumir alimentos muy salados o condimentados o un amplio consumo de granos, entre otros. Una relación causal entre CG y otros factores incluyendo la infección con Helicobacter pylori no ha sido confirmada, excepto para los fumadores y la comida salada. Por otra parte se ha visto que decrece el riesgo de CG con el consumo frecuente de vegetales verdeamarillos, frutas y té verde, que incluye betacarotenos, Vitamina $\mathrm{A}, \mathrm{C}$, entre otros factores que han sido definidos en estudios previos.

Con el objeto de clarificar la influencia ambiental y factores asociados con el riesgo de CG hicimos un estudio comparativo en áreas de alto riesgo (HRA) y áreas de bajo riesgo (LRA) para CG en la provincia de Jiangsu en China.

Este estudio comparativo de los factores ambientales mostró que las regiones de bajo riesgo (LRA) se asociaban a un alto consumo de ajo. Además se observaron factores coayudantes como el P4502E1 y el polimorfismo de HLA DR B 1, que se encontró, jugaban un papel complementario en la disminución del riesgo para el CG.

\section{Introduction}

Northeastern Asia, i.e., Japan, Korea and China, is

1 Division of Epidemiology, Aichi Cancer Center Research Institute, Japan

2 Department of Virology, Faculty of Medicine, Kagoshima University, Japan. one of the highest risk areas in the world for gastric cancer (GC), although GC is also common in Central and South American countries such as Costa Rica, Colombia and Chile, in addition to Latin European countries such as Italy and Portugal.

Increased risk of gastric cancer has been reported for smoking, alcohol drinking and dietary habits such as frequent consumption of salty food and hard-baked food, large consumption of grains, and others. A causal relationship between gastric cancer and these factors, including Helicobacter pylori infection, has not yet been well confirmed except in the cases of smoking and salty food. Meanwhile, a decreased risk of gastric and lung cancers with frequent consumption of greenyellow vegetables and fruit, which include betacrotene and vitamin A, C, epigallocatechin and others, has been addressed in many previous studies.

As the risk of GC is strongly associated with dietary factors, and dietary habits vary with ethnic groups, macrogeographic and micrographic comparative studies provide fruitful information for the clarification of the risk factors for GC. In the present paper, we compare the incidence and mortality for $\mathrm{GC}$, and the risk and protective factors for GC in Japan, China and South America. We also introduce the preliminary results of an ongoing comparative epidemiological study of environmental and host factors for GC in high- and low-risk areas of China.

\section{Incidence and Mortality Rates for GC}

\section{Incidence rates for GC in various countries}

According to cancer registry data in five continents, northeastern Asian countries such as Japan, Korea and China, show the highest incidence rates for GC in the world (Figure 1). South and Central American countries, especially Costa Rica, also show high incidence rates for GC. Among European countries, the incidence rate of GC is relatively high in Italy. The US, and India, and African countries such as 

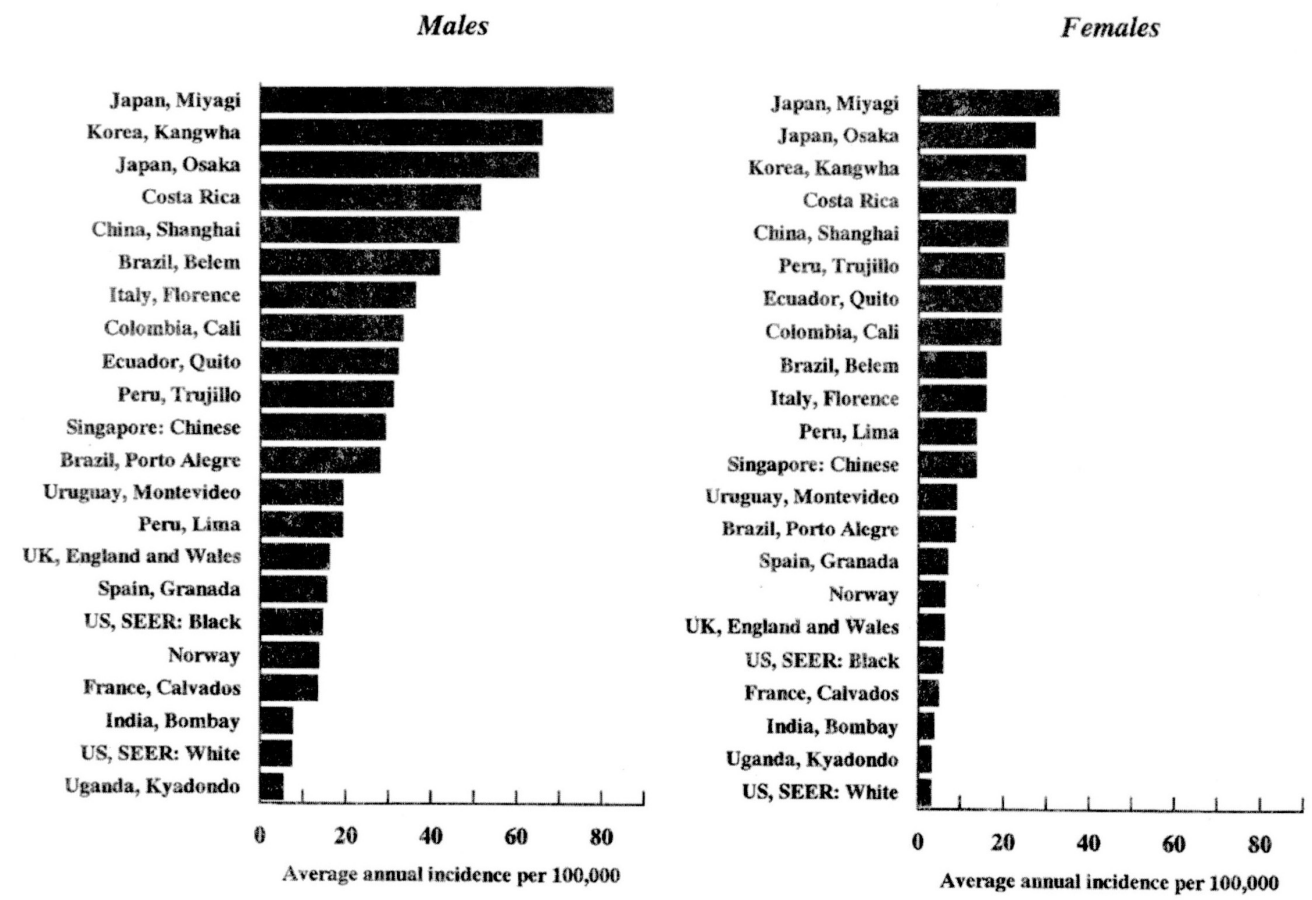

Fig. 1. Age-adjusted incidence rates for gastric cancer in selected countries for five continents (Parkin et al, 1997).

Uganda, have lower incidence rates for GC. These international variations are not different for males and females, but the incidence rate is more than twice as high in males as in females overall.

When the incidence rates for $\mathrm{GC}$ are compared for Japanese in Japan and Japanese immigrants to the US, the rate is around three times lower in Japanese emigrants than in Japanese in Japan. This evidence suggests that the change in environmental exposure to lifestyles, such as dietary habit, influences the incidence of GC even in identical genetic backgrounds.

\section{Incidence rates for selected cancer sites in South America and Japan}

When the incidence in selected cancer sites is compared for Cali in Colombia, Lima in Peru, and Miyagi in Japan, GC is found to be the leading form of cancer incidence in these three areas in males (Figure 2). The incidence rate in Japanese males is the highest of all. In females, breast and cervical cancer are the first and second leading forms of cancer incidence in Colombia and Peru, while GC is the third. However, GC is the most common in Japanese females, and its incidence rate is much higher than those in Colombian and Peruvian females.

Rios-Dalenz et al. estimated cancer incidence in residents of La Paz in 1981, using a hospital based cancer registry system. GC was found to be the leading form of cancer incidence in males, and the fifth in females.

$\mathrm{GC}$ is a common major target of cancer prevention both in South America and Japan.

\section{Time trend for GC mortality}

The mortality rate for GC similarly decreased in Japan and Chile from 1963 to 1987 (Figure 3). The mortality rate for cancer in all sites decreased in Japanese females, and in Chilean males and females during this period, while the rate for Japanese males showed a tendency to increase with time. It is suspected that the improvement of food storage systems, including the use of refrigerators, and advances in medical treatment may be responsible for these decreasing trends. In Japan, a decrease in salt consumption and the spread of reliable screening systems for early detection of GC have also played an important role in the decline of GC incidence. 

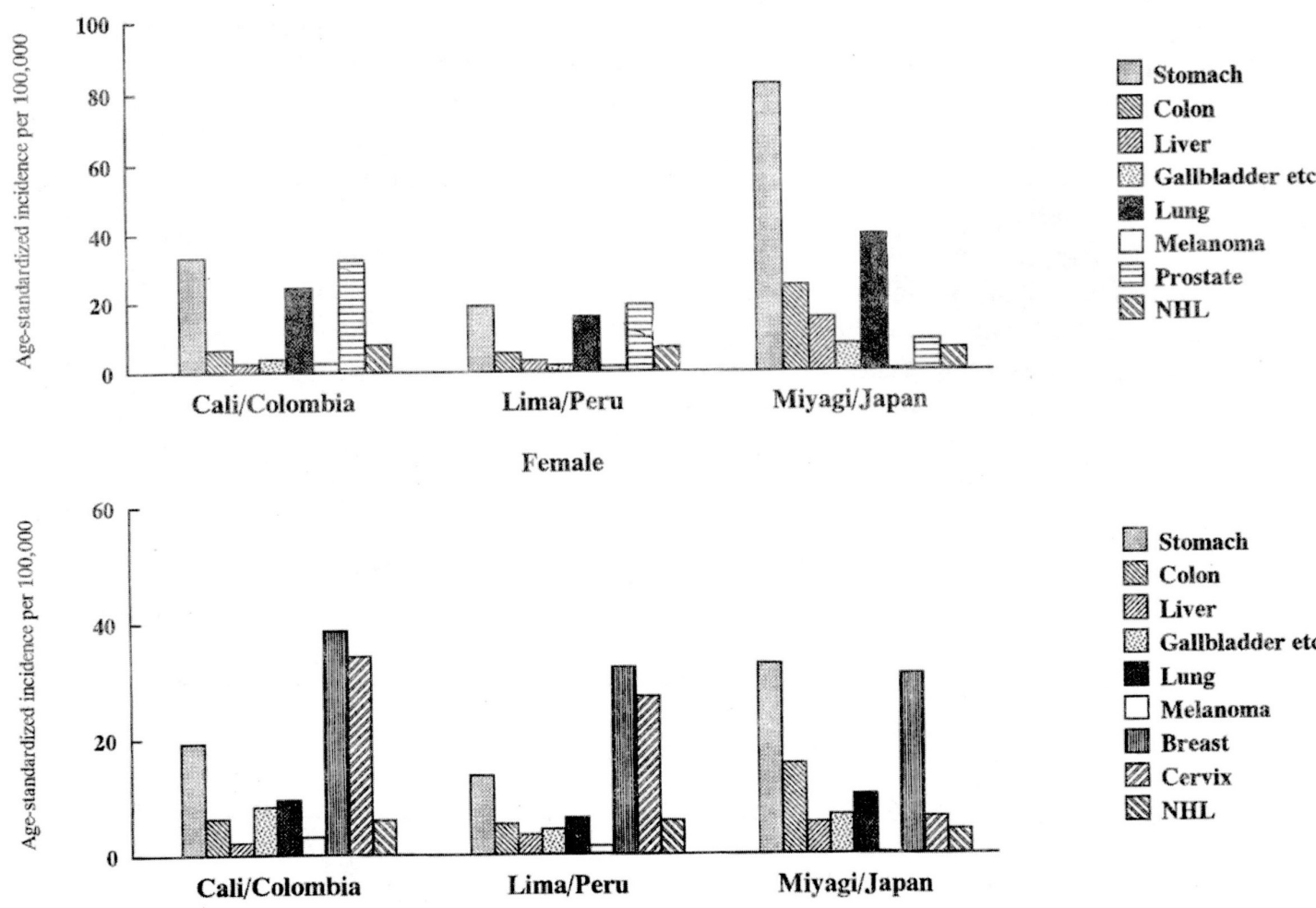

$\square$ Stomach
$\mathbb{Q}$ Colon
Liver
Gallbladder etc
Lung
$\square$ Melanoma
Breast
$\mathbb{Q}$ Cervix
NHL

Fig. 2. Age-adjusted incidence rates for selected cancer sites of cancer in Cali in Colombia, in Lima in Peru and Miyagi in Japan (Parkin et al, 1977).

Males

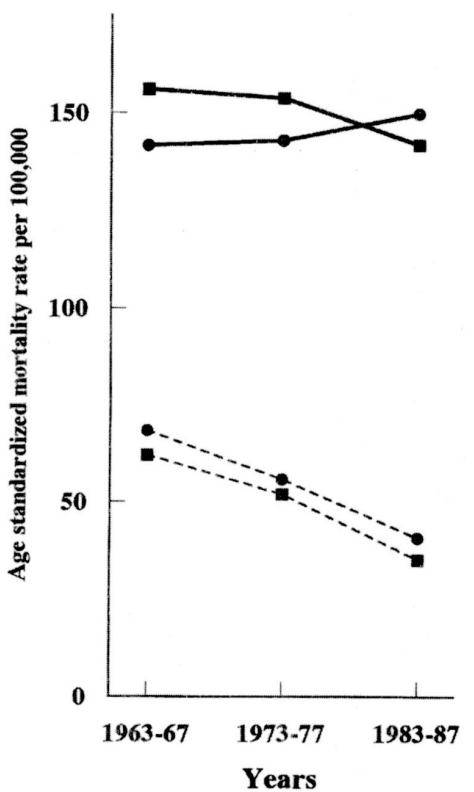

Females

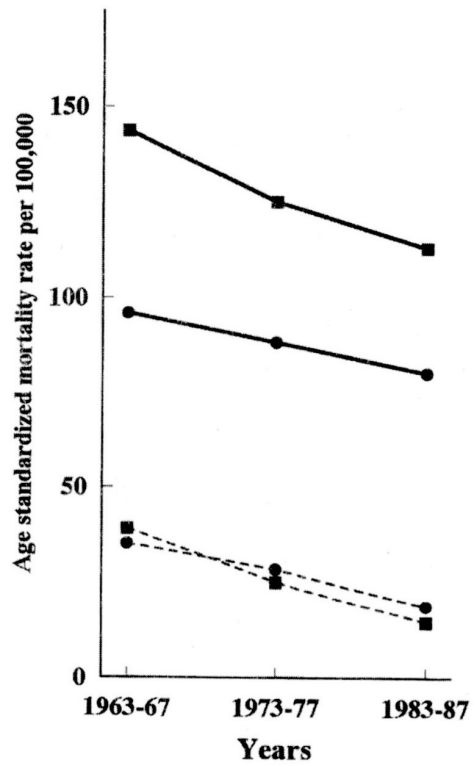

Fig. 3. Trends in age-adjusted mortality rates for all sites of cancer and gastric cancer in Chile and Japan between 1963 and 1987 (Aoki et al, 1992). 


\section{Risk and Protective Factors for GC}

\section{Andean countries}

The risk factors for atrophic gastritis and intestinal metaplasia of the stomach have been addressed in one cohort and three case-control studies of Andean residents (Table 1). The prevalence of these diseases has been positively associated with abundant use of lettuce, and inversely associated with abundant use of corn. The prevalence of atrophic gastritis is higher in people aged over 30 years than those aged 30 or younger, and in those whose mothers have been affected by atrophic gastritis. Increased odds ratios (ORs) for intestinal metaplasia and dysplasia have been observed in the people with a higher proportion of detectable nitrate 19. Higher salt consumption measured by urine sample has been associated with an increased risk of atrophic gastritis and dysplasia.

The number of epidemiological studies of the risk of GC in Andean countries is limited. Armijo et al. have investigated the risk of GC in a case-control study, and found that agricultural occupations were associated with an increased risk of GC.

In ecological studies, urinary and salivary nitrate and nitrite, higher consumption of faya beans and salt, and lower consumption of potassium have been associated with high risk of GC. Higher consumption of fresh fruit and vegetables has been inversely associated with risk of GC.

\section{Japan}

Frequent consumption of salty food, salted and/ or dried fish, pickled vegetables, spicy food, broiled fish or meat, rice, and smoking and drinking, and

\begin{tabular}{|c|c|c|c|}
\hline $\begin{array}{l}\text { Authors } \\
\text { (country) } \\
\text { year }\end{array}$ & Study design & Subjects & Results \\
\hline $\begin{array}{l}\text { Cuello } \\
\text { (Colombia) } \\
1976\end{array}$ & Ecological & $\begin{array}{l}5 \text { areas } \\
n=335\end{array}$ & $\begin{array}{l}\text { Urinary and salivary nitrate and nitrite by areas } \\
\text { High risk: higher value } \\
\text { Low risk: lower value }\end{array}$ \\
\hline $\begin{array}{l}\text { Haenszel } \\
\text { (Colombia) } \\
1976\end{array}$ & $\begin{array}{l}\text { Case-control } \\
\text { control }\end{array}$ & Hospital-based & $\begin{array}{l}\text { Prevalence of intestinal metaplasia and atrophic gastritis } \\
\text { High risk: abundant use of lettuce } \\
\text { Low risk: abundant use of corn }\end{array}$ \\
\hline $\begin{array}{l}\text { Armijo } \\
\text { (Chile) } \\
1981\end{array}$ & Case-control & 360 cases & $\begin{array}{l}\text { Increased risk: } \\
\text { Longer-term residence in high risk area in early life } \\
\text { for cases with intestinal-type Agricultural occupation }\end{array}$ \\
\hline $\begin{array}{l}\text { Correa } \\
\text { (Colombia) }\end{array}$ & Ecological & $\begin{array}{l}4 \text { subgroups } \\
\mathrm{n}=1277\end{array}$ & $\begin{array}{l}\text { Nutrition survey } \\
\text { High risk: higher comsumption of fava bean, salt } \\
\text { lower consumption of potassium } \\
\text { Low risk: higher comsumption of fresh fruit and } \\
\text { vegetable }\end{array}$ \\
\hline $\begin{array}{l}\text { Bonney } \\
\text { (Colombia) } \\
1986\end{array}$ & Cohort & $\begin{array}{l}110 \text { families } \\
\mathrm{n}=557\end{array}$ & $\begin{array}{l}\text { Prevalence rate for atrophic gastritis } \\
\text { By age; } 28 \% \text { (<31 yrs) vs. } 56 \% \text { ( }>30 \text { yrs) } \\
\text { By mother; } 7 \% \text { (unaffected) vs. } 48 \% \text { (affected) }\end{array}$ \\
\hline $\begin{array}{l}\text { Chen } \\
\text { (Colombia) } \\
1990\end{array}$ & Case-control & High-risk pop. & $\begin{array}{l}\text { ORs for proportion of detectable nitrate } \\
4.4 \text { for intestinal metaplasia } \\
27.7 \text { for dysplasia }\end{array}$ \\
\hline $\begin{array}{l}\text { Chen } \\
\text { (Colombia) } \\
1990\end{array}$ & Case-control & $\begin{array}{l}\text { High-risk pop. } \\
n=263\end{array}$ & $\begin{array}{l}\text { ORs for salt consumtion measured by une samples } \\
2.5 \text { for atrophic gastritis } \\
7.2 \text { for dysplasia } \\
\text { OR for add in salt to food at table } \\
1.8 \text { for whole precacerous lesions }\end{array}$ \\
\hline
\end{tabular}

Table 1. Epidemiological studies of risk of stomach cancer in the Andes. 


\begin{tabular}{|c|c|c|c|c|}
\hline $\begin{array}{l}\text { Authors } \\
\text { year }\end{array}$ & Study design & Subjects & $\begin{array}{l}\text { Positive } \\
\text { Association }\end{array}$ & $\begin{array}{l}\text { Inverse } \\
\text { Association }\end{array}$ \\
\hline $\begin{array}{l}\text { Segi } \\
1957\end{array}$ & Case-control & $\begin{array}{l}\text { Hospital- and } \\
\text { pop.-based }\end{array}$ & $\begin{array}{l}\text { Smoking, drinking } \\
\text { Salted food } \\
\text { Rice }\end{array}$ & Soybean paste soup \\
\hline $\begin{array}{l}\text { Sato } \\
1959\end{array}$ & Ecological & Pop.-based & Salted food & \\
\hline $\begin{array}{l}\text { Hirayama } \\
1982\end{array}$ & Cohort & $\begin{array}{l}\text { Pop.-based } \\
\mathrm{n}=265,118\end{array}$ & --- & Green yellow vegetables \\
\hline $\begin{array}{l}\text { Hirayama } \\
1982\end{array}$ & Cohort & $\begin{array}{l}\text { Pop.-based } \\
n=265,118\end{array}$ & --- & Soybean paste soup \\
\hline $\begin{array}{l}\text { Tominaga } \\
1982\end{array}$ & Ecological & Pop.-based & $\begin{array}{l}\text { Cereals (rice) } \\
\text { Salty food (salted fish) }\end{array}$ & Milk and milk products, meat \\
\hline $\begin{array}{l}\text { Ikeda } \\
1983\end{array}$ & Cohort & $\begin{array}{l}\text { Pop.-based } \\
\mathrm{n}=7,553\end{array}$ & Broiled fish & \\
\hline $\begin{array}{l}\text { Tajima } \\
1985\end{array}$ & Case control & Hospital-based & $\begin{array}{l}\text { Salted/dried fish } \\
\text { Pickled vegetables } \\
\text { Smoking (male) }\end{array}$ & \\
\hline $\begin{array}{l}\text { Kono } \\
1987\end{array}$ & Cohort & $\begin{array}{l}\text { Male physicians } \\
\mathrm{n}=5,130\end{array}$ & Smoking & \\
\hline $\begin{array}{l}\text { Kono } \\
1988\end{array}$ & Case control & $\begin{array}{l}\text { Hospital-and } \\
\text { pop.-based }\end{array}$ & Smoking & Fruit, green tea \\
\hline $\begin{array}{l}\text { Kato } \\
1992\end{array}$ & Cohort & $\begin{array}{l}\text { Pop.-based } \\
\mathrm{n}=9,753\end{array}$ & $\begin{array}{l}\text { Smoking, drinking } \\
\text { Broiling of meat } \\
\text { Traditional style Japane } \\
\text { Family history }\end{array}$ & ese salted preparation \\
\hline $\begin{array}{l}\text { Hoshiyama } \\
1992\end{array}$ & Case-control & $\begin{array}{l}\text { Hospital-and } \\
\text { pop.-based }\end{array}$ & -- & Fresh vegetables \\
\hline $\begin{array}{l}\text { Inoue } \\
1994\end{array}$ & Case-control & Hospital-based & $\begin{array}{l}\text { Smoking with drinking } \\
\text { Greasy food (cardia) }\end{array}$ & $\begin{array}{l}\text { Fresh vegetables } \\
\text { Western-style breakfast } \\
\text { (antrum) }\end{array}$ \\
\hline $\begin{array}{l}\text { Fakuda } \\
1995\end{array}$ & Case-control & Hospital-based & $\begin{array}{l}\text { Helicobacter pylori } \\
\text { adjusted for atrophic gas } \\
\text { pepsinogen } \mathrm{I} / \mathrm{II}\end{array}$ & astritis by level of \\
\hline $\begin{array}{l}\text { Inoue } \\
1996\end{array}$ & Cohort & $\begin{array}{l}\text { Subject with } \\
\text { gastroscopic ex. }\end{array}$ & $\begin{array}{l}\text { Atrophic gastritis } \\
\text { Family history, spicy } \\
\text { food }\end{array}$ & $\begin{array}{l}\text { Reduced consumption of } \\
\text { salty food Easily } \\
\text { digested food }\end{array}$ \\
\hline $\begin{array}{l}\text { Inoue } \\
1998\end{array}$ & Case-control & Hospital-based & --- & Green tea \\
\hline
\end{tabular}

Table 2. Epidemiological studies of risk of stomach cancer in Japan. 
$\mathrm{AMR}^{\mathrm{a})}$ per 100,000

\begin{tabular}{|c|c|c|c|c|c|c|c|c|c|c|}
\hline \multirow[t]{2}{*}{ Sites of cancer } & \multicolumn{5}{|c|}{ Males } & \multicolumn{5}{|c|}{ Females } \\
\hline & Yangzhong & Huajan & Pizhou & Nanjing & Japan & Yangzhong & Huajan & Pizhou & Nanjing & Japan \\
\hline Esophagus & 104.3 & 129.2 & 39.5 & 30.1 & 7.0 & 88.3 & 115.0 & 18.2 & 14.0 & 1.0 \\
\hline Stomach & 147.1 & 80.7 & 28.2 & 65.2 & 34.3 & 80.5 & 49.8 & 12.6 & 26.0 & 15.0 \\
\hline Colorectum & 12.4 & 5.6 & 2.9 & 14.1 & 15.0 & 9.0 & 4.7 & 1.5 & 11.0 & 10.0 \\
\hline Liver & 60.6 & 43.0 & 53.4 & 28.9 & 20.9 & 24.5 & 17.1 & 17.9 & 9.7 & 5.5 \\
\hline Lung & 26.5 & 21.7 & 42.3 & 43.3 & 30.4 & 7.5 & 7.9 & 16.3 & 13.5 & 7.9 \\
\hline All sites & 389.3 & 308.9 & 186.4 & 310.0 & 150.5 & 247.6 & 221.4 & 84.7 & 132.5 & 76.1 \\
\hline
\end{tabular}

a) Age adjusted mortality rate, using Segi-Doll's World Population.

Table 3. Comparison by sex of age adjust mortality rates (AMRs) for selected cancer in Yangzhong, Huaian, Pizhou and Nanjing, in China and Japan.

smoking with drinking - have been associated with increased risk of GC in Japan. Family history of GC, Helicobacter pylori infection, and atrophic gastritis have been also related to increased risk of GC. Decreased risk of GC has been observed for frequent consumption of green yellow vegetables, fresh vegetables, fruit, soybean paste soup and green tea, easily digested food, and reduced consumption of salty food. The significance of risk factors has been confirmed in an ecological study.

Some of these factors may be available to play a role in GC prevention in Andean areas.

\section{Comparative Study of Environmental and Host Factors for GC in China}

To clarify the environmental and host factors associated with risk of $\mathrm{GC}$, we are conducting a comparative study of a high risk area (HRA), Yangzhong City, and a low risk area (LRA), Pizhou City both in Jiangsu Province, China. The mortality rate for GC in HRA is more than four times higher than that in Japan, and about twice as high as that in Nanjing, the provincial capital. On the other hand, the mortality rate for GC in LRA is lower than that in Japan (Table 3).

A comparative study of the ecological factors shows that greater amounts of allium vegetables consumption, such as garlic, were consumed in the LRA, and tomatoes, raw vegetables, fruit, beans and soybean products were also consumed more frequently. A case-control study in the HRA shows that frequent consumption of allium vegetables, such as garlic, welsh onion, onion and leek, decreaces the ORs for GC (Table 4). The

\begin{tabular}{|c|c|c|c|c|}
\hline & Controls & \multicolumn{3}{|c|}{ Gastric cancer } \\
\hline & No. & No. & $\mathrm{OR}^{*}$ & $95 \% \mathrm{CI}$ \\
\hline \multicolumn{5}{|l|}{ Garlic } \\
\hline$<1$ time/month & 24 & 65 & 1.00 & \\
\hline 1-3 times/month & 40 & 37 & 0.33 & $0.17-0.63$ \\
\hline$>1$ time/week & 170 & 51 & 0.11 & $0.06-0.20$ \\
\hline \multicolumn{5}{|c|}{ Green Chinese onion (Welsh onion) } \\
\hline$<1$ time/month & 34 & 94 & 1.00 & \\
\hline 1-3 times/month & 32 & 35 & 0.41 & $0.22-0.76$ \\
\hline$\geq 1$ time/week & 168 & 24 & 0.05 & $0.03-0.09$ \\
\hline \multicolumn{5}{|l|}{ Onion } \\
\hline$<1$ time/month & 67 & 137 & 1.00 & \\
\hline 1-3 times/month & 118 & 14 & 0.05 & $0.03-0.10$ \\
\hline$\geq 1$ time/week & 49 & 2 & 0.02 & $0.01-0.10$ \\
\hline \multicolumn{5}{|l|}{ Chinese chives } \\
\hline$<1$ time/month & 66 & 82 & 1.00 & \\
\hline 1-3 times/month & 155 & 69 & 0.36 & $0.23-0.55$ \\
\hline$\geq 1$ time/week & 13 & 2 & 0.13 & $0.03-0.59$ \\
\hline
\end{tabular}

* Estimated by logistic regression model including age and sex.

Table 4. Estimated ORs and their 95\% CI

for gastric cancer cases according to consumption of allium vegetables.

adjusted ORs of GC for frequent consumption of allium vegetables were also significantly lower in the LRA.

To investigate host factors, we collected DNA samples from peripheral blood mononuclear cells of GC patients, their families and health controls, and examined the genetic polymorphism of $\mathrm{P} 450$ 2E1 and HLA DRB1 alleles. These host factors were compared to subjects of a HRA, Huaian City, and those of the LRA, Pizhou City. The prevalence rate of a variant genotype of P450 2E1 polymorphism, Rsal site-absent homozygote, which suppresses the 
enzyme activity of procarcinogens, was found to be $2 \%$ in the HRA and $14 \%$ in the LRA, although this difference was not statistically significant. This variant genotype was not also significantly associated with a decreased risk for gastric and esophageal cancers. The ethnic background, examined by HLA study, was slightly different in both areas, and DRB $1 * 02$ allele type was more common among cancer cases. The seroepidemiological study showed that the prevalence of Helicobacter pylori infection tended to be less common in the LRA.

From this evidence, it is suggested that frequent consumption of allium vegetables is involved in the lower incidence of OC, and the host factors, P450 2E 1 and HLA DRB 1 polymorphisms, play little role in the risk of $\mathrm{GC}$ in the areas studied.

In summary, GC is a common and important cancer urgently requiring prevention in South America, China and Japan. The control of GC development may depend on environmental factors, which therefore deserve clarification. Cancer prevention by modification of lifestyle is the most effective weapon in the fight to bring about a decline in cancer mortality.

\section{REFERENCES}

AOKI, K., KURIHARA, K., HAYAKAWA, N., SUZUKI, S., 1992 eds. Death rate for malignant neoplasm for selected sites by sex and five-year age group in 33 countries 1953-57 to 1983-87. Nagoya, Japan: UICC.

ARMIJO, R., ORELLANA, M., MEDINA, E., COULSON, AH., 1981 SAYRE, J. W., DETELS, R. Epidemiology of gastric cancer in Chile: 1- Case-control study. Int. J. Epidemiol. 10: 53-6.

BJELKE, E. Dietary vitamin A and human lung 1975 cancer. Int. J. Cancer; 15: 561-5.

BONNEY, G. E., ELSTON, R. C., CORREA, P., et al. Genetic 1986 etiology of gastric carcinoma: I. Chronic atrophic gastritis. Genet. Epidemiol. 3: 213-24.

CHEN, V. W., ABU ELYAZEED, R. R., ZAVALA, D. E., 1990 KTSANES,V.K., HAENSZEL, W. CUELLO, C., et al. Risk factors of gastric precancerous lesions in a highrisk Colombian population. I. Salt. Nutr. Cancer 13(1-2): 9-65.

CHEN, V. W., ABU ELYAZEED, R. R., ZAVALA, D. E., 1990 HAENSZEL, W., KTSANES, V.K., RICE, J., et al. Risk factors of gastric precancerous lesions in a high-risk Colombian population. 11. Nitrate and nitrite. Nutr. Cancer 13(12): 67-72.

CORREA, P., HAENSZEL, W., CUELLO, C., et al. A model 1975 for gastric cancer epidemiology. Lancet 2: 58-60.

CORREA, E, CUELlO, C., FAJARDO, L. F., HAENSZEL, 1983 W., BOLANOS, O., DE RAMIREZ, B. Diet and gastric cancer: nutrition survey in a high-risk area. J. Natl. Cancer Inst. 70: 673-8

CUEllo, C., CORREA, P., HAENSZEL, W., GORDILlO, 1976 G., BROWN, C., ARCHER, M., et al. Gastric cancer in Colombia. I. Cancer risk and suspect environmental agents. J. Natl. Cancer Inst. 57: 1015-20.

FUKUDA, H., SAITO, D., HAYASHI, 5., HISAI, H., ONO, 1995 H., YOSHIDA, 5., etal.Helicobacterpylori infection, serum pepsinogen level and gastric cancer: a case-control study in
Japan. Jpn. J. Cancer Res. 86: 64-71.

HAENSZEL, W ., CORREA, P., CUELlO, C., et al. Gastric 1976 cancer in Colombia. II. Case-control epidemiologic study of precursor Iesions. J. Natl. Cancer Inst. 57:1021-6.

HIRAYAMA, T. Relationship of soybean paste soup intake 1982 t to gastric cancer risk. Nutr. Cancer 3: 223-33.

HIRAYAMA, T. Does daily intake of green-yellow vegetables 1982 reduce the risk of cancer in man? An example of the application of epidemiological methods to the identification of individuals at low risk. IARC Scientific Publications 39:53 140.

HOSHIYAMA, Y., SASABA, T. A. case-control study of 1992 stomach cancer and its relation to diet, cigarettes, and alcohol consumption in Saitama Prefecture, Japan. Cancer Causes Control 3: 441-8.

HU. J., ZHANG, S., JIA, E., et al. Diet and cancer of the 1988 stomach: a case-control study in China. Int. J. Cancer 41: 331-5.

IKEDA, M., YOSHIMOTO, K., YOSHIMURA, T., et al. A 1983 cohort study on the possible association between broiled fish and cancer. Gann 74 . 640-8.

International Agency for Research on Cancer. IARC 1994 Monographs on the Evaluation of Cartinogenic Risks to Humans. Vol. 61: Schistosomes, Liver Flukes and Helicobacter pylori. Lyon: IARC.

KATO, 1., TOMINAGA, S., MATSUmoto, K. A. 1992 prospective study of stomach cancer among a rural Japanese population: a 6-year survey. Jpn. J. Cancer Res. 83: 568-75.

KONO, S., IKEDA, M., TOKUDOME, S., et al. Cigarette 1987 smoking, alcohol and cancer mortality: a cohort study of male Japanese physicians. Jap. J. Cancer Res. (Gann) 78: 1323-8.

KONO, S., IKEDA, M., TOKUDOME, S., KURATSUNE, 1988 M. A case-control study of gastrie cancer and diet in northern Kyushu, Japan. Jpn. 
J. Cancer Res. 79: 1067-74.

INOUE, M., TAJIMA, K., HIROSE, K., KUROISHI, T., 1994 GAO, CM., KITOH, T. Life-style and subsite of gastric cancer joint effect of smoking and drinking habits. Int. J. Cancer 56: 494-9.

INOUE, M., TAJIMA, K., KOBAYASHI, 5., SUZUKI, T., 1996 MATSUURA, A., NAKAMURA, T., et al. Protective factor against progression from atrophic gastritis to gastric cancer-data from a cohort study in Japan. Int. J. Cancer 66:309-14

INOUE, M., TAJIMA, K., HIROSE, K.. HAMAJIMA, N., 1998 TAKEZAKI, T., KUROISHI, T., et al. Tea and coffee consumptiun and the risk of digestive tract cancers: data from a comparative casereferent study in Japan. Cancer Causes Control 9: 209-16

MACLAUGHLIN, J.K., HRUBEC, Z., BLOT, W.J.,

1990 FRAUMENI Jr, F.J. Stomach cancer and cigarelte smoking among US veterans. Cancer Res. 50: 3804.

PARKIN, D., MUIR, C., WHELAN, 5., FERLAY, J., 1997 RAYMOND, L., YOUNG, J. eds Cancer incidence in five continents, Vol. VII. Lyon, France: International Agency for Research on Cancer IARC Sci. Pub. No. 143: 822-3.

RIOS DALENZ, J., CORREA, P., HAENSZEL, W. Morbidity 1998 from cancer in La Paz, Bolivia. Int. J.
Cancer 28: 307-14

SATO, T., FUKUYAMA, T., SUZUKI, T., et al. The 1959 relationship between gastric cancer mortality rate and salted food consumption in several places in Japan. Bull. Inst. pub. Health 8: 187-98.

SEGI, M., FUKUSHIMA, 1., FUJISAKU, 5. el al. An 1957 epidemiological study un cancer in Japan. Gann 48 Suppl: s1-63.

SHEKELLE, R.B., LEPPER, M., LIU, 5., et al. Dietary 1981 vitamin A and risk of cancer in the Western Electric study. Lancet 2: 1185- 90.

TAJIMA, K., TOMINAGA, S. Dietary habits and gastro1985 intestinal cancers: a comparative casecontrol study of stomach and large intestinal cancers in Nagoya, Japan. Jap. J. Cancer Res. (Gann) 76: 705-16.

TAKEZAKI, T., GAO, C., DING, J., LIU, T., LI, M., 1999 TAJIMA, K. Comparative study of lifestyles of residents in high and low risk areas for gastrie cancer in Jiangsu Province, China; with special reference to allium vegetables. J. Epidemiol 9 (in press).

TOMINAGA, S. OGAWA, H., KUROISHI, T. Usefulness of 1982 currelation analyses in the epidemiology of stomach cancer. Natl. Cancer Inst. Monogr. 62: 135-40.

WYNDER, E.L . KMET, J., DUNGAL, N., et al. An., 1963 epidemiological investigation of gastric cancer. Cancer 16: 1461-94. 